\title{
Visual perception of five-year-old Afrikaans-speaking children in Bloemfontein using the Beery VMI-6, DTVP-3 and TVPS-3: A follow up study of their English-speaking counterparts in Bloemfontein
}

\author{
Marieta Visser, BOT (UFS), MSc (OT) (WITS) \\ Lecturer, Department of Occupational Therapy, School for Allied Health Professions, Faculty of Health Sciences, University of the \\ Free State, Bloemfontein
}

\author{
Mariette Nel, MMedSc (Biostatistics) (UFS) \\ Department of Biostatistics, Faculty of Health Sciences, University of the Free State, Bloemfontein
}

Background and aim: Previous research investigated the latest versions of the Beery-Buktenica Developmental Test of Visual-motor Integration $6^{\text {th }}$ edition (Beery VMI-6), Development Test of Visual Perception $3^{\text {rd }}$ edition (DTVP-3) and Test of Visual Perceptual Skills $3^{\text {rd }}$ edition (TVPS-3) on five-year-old English-speaking children. This study aimed to extend the investigation, to five-year-old Afrikaansspeaking children, and to compare the results to previous findings on English-speaking children of a similar age.

Methods: A quantitative, cross-sectional investigation into the visual perception and visual-motor performance of five-year-old Afrikaans-speaking children $(n=52)$ was conducted at Afrikaans Language of Learning and Teaching (ALOLT) schools in Bloemfontein, by using these tests according to the prescribed procedures, in a specific order and with adequate breaks between tests.

Results: Both language groups' performance on the Beery VMI-6 and DTVP-3 compared well to the American normative sample, but below average on all the TVPS-3 composite scores. The Beery VMI-6 motor coordination sub-test yielded statistically significant gender differences. No significant language differences were noted in the three tests. A statistically significant difference was identified between form constancy and visual closure sub-tests of the DTVP-3 and the TVPS-3, and when the Beery VMI-6 visual-motor integration sub-test was compared to the DTVP-3copying sub-test.

Conclusions: Occupational therapists are encouraged to consider the suitability of the three tests, and further research in this field is recommended.

Key words: visual perceptual tests; visual-motor performance; five-year-old children; Beery VMI-6; DTVP-3; TVPS-3

\section{INTRODUCTION}

During the evaluation process of obtaining and interpreting data necessary for intervention, specific tools or instruments, called assessment instruments, are used'. Assessment is a fundamental part of the occupational therapy process, through which body function and structure, activity and participation, as framed within the International Classification for Function and Disability (ICF) ${ }^{2}$, are analysed. In order to provide reliable and valid assessment findings, therapists need to critically evaluate the suitability of assessment instruments for the population these instruments are used on $^{3}$.

Assessment instruments used worldwide to specifically assess visual perceptual and visual-motor abilities include the BeeryBuktenica Developmental Test of Visual-motor Integration $6^{\text {th }}$ edition (Beery VMI-6) ${ }^{4}$, Development Test of Visual Perception $3^{\text {rd }}$ edition (DTVP-3 $)^{5}$ and Test of Visual Perceptual Skills $3^{\text {rd }}$ edition $(\text { TVPS }-3)^{6}$. The three assessment instruments explored in this study were designed and standardised in the United States (USA), and cultural differences may account for discrepancies in difficulty levels of some visual perceptual and visual-motor activities of these assessment instruments ${ }^{7}$. Hence the measurement properties and suitability of these instruments should be researched in the cultural context in which it will be used ${ }^{8}$.

Research on these previous versions of these instruments have been reported, but limited information is available on the current versions' suitability within different cultural and language groups. Research on the latest versions performed on populations other than the American normative samples (on which all three tests were standardised), included studies in Australia ${ }^{8-14}$, China ${ }^{15-17}$, and Taiwan ${ }^{18}$.

In two South African studies ${ }^{7,19}$, the suitability of these tests has been described, indicating that certain aspects of these tests might not be suitable in their current form to be used with the diverse range of cultural, language and socio-economic groups represented in South African children. The performance of a sample of fiveyear-old English-speaking children in a previous study indicated consistencies with sub-tests of the Beery VMI-6 and DTVP-3, but significant differences with most sub-tests of the TVPS-3.

Therapists in South Africa continue to show preference to use the both older and the newest versions of these tests ${ }^{20,21}$, because currently, no standardised contextual relevant or culture-specific visual perceptual and visual-motor assessment instruments are available. However, when such assessments instruments are used during the evaluation process, occupational therapists should be mindful of the manner in which they use these tests, interpret results and make recommendations for practice ${ }^{7}$. Furthermore, in countries where research has not been sufficient to describe the suitability, various authors have concurred that "clinicians should exercise caution when using an assessment instrument in communities and cultures outside the ones on which it was standardised"22-24.

The aim of this study was to describe the visual perception and visual-motor performance of five-year-old ( 5 years 6 months to 5 years II months) Afrikaans-speaking children in Bloemfontein, South Africa, by using the Beery VMI-6, DTVP-3 and TVPS-3 measurement instruments' accepted norms as a follow-up study, and 
to compare the results to previous findings on English-speaking children of a similar age ${ }^{7}$.

\section{LITERATURE REVIEW}

Visual perception is an occupational performance skill needed to support engagement and participation in daily life occupations. Both visual perception and visual-motor integration are considered functionally important to childhood occupations' ${ }^{\prime}$, and play an important role on many levels in a child's daily functioning and development. Furthermore, research also confirmed its importance in the performance of various academic tasks such as reading, writing, and mathematics ${ }^{6,25,26}$.

Visual perception is the ability to identify, organise, ascribe meaning to and provide sense of what is seen in the environment ${ }^{6}$, whereas visual-motor performance are essential for translating what is seen into an appropriate motor output, such as copying a shape or drawing between lines. Some visual perceptual assessment instruments categorise visual perception into motor-reduced and motor-enhanced sub-tests/sections ${ }^{11}$. For the purpose of this study the term visual-motor performance ${ }^{7}$ refers to these motor enhanced sub-tests, such as visual-motor integration, visual-motor speed, and eye-hand coordination. The term visual-motor performance is used interchangeably in the literature with visual-motor functions, and visual motor skills ${ }^{27}$.

Visual perception and visual-motor performance can be assessed during clinical observations, informal assessments and by means of standardised assessment instruments ${ }^{25}$. According to Rudman ${ }^{3}$, therapists should evaluate assessment instruments critically according to certain attributes, such as clinical utility (e.g., time demands, availability in the public domain, cost, prefabricated equipment/ material), standardisation, purpose (e.g., descriptive, predictive or evaluative), psychometric properties (e.g., reliability and validity), and the patient's perspective.

Table I (page 33) provides a summarised overview of the three assessment instruments ${ }^{4-6,13,14}$. This summary aims to orientate the reader towards the characteristics and measurement properties of the three tests as compiled from the manuals and the literature. Although the latest version of the TVPS, namely the TVPS-4, had been published in $2017^{28}$, it was not available to the researchers at the time of the study.

With regard to the South African context, research on the previous versions of these tests have found unique differences in the South African population as described by authors who published their work and as described in the previous article's literture ${ }^{7}$. However this article reports on the latest versions of the three tests.

Table II (page 34) summarises previously published research on the Beery VMI-6, DTVP-3 and TVPS- 3 available during the study, excluding studies involving specific diagnoses such as Down syndrome and autism.

\section{METHODOLOGY}

\section{Design}

A quantitative, cross-sectional study design was applied. The first of this series of studies that reported on children from the English Language of Learning and Teaching (ELOLT) schools ${ }^{7}$, was followed up by this study on children from the Afrikaans Language of Learning and Teaching (ALOLT) schools.

\section{Population and sampling}

The study sample was recruited from the ALOLT public and private schools with Grade pre-R and Grade R classes in Bloemfontein. A list of all of the registered ALOLT schools in Bloemfontein was acquired from the education management information system (EMIS) section. EMIS Portal of the Free State Department of Basic Education ${ }^{29}$ : The public report folder "Learner Numbers File, Motheo Learners per Grade SCHOOL 30 June 2016" contains a list of all schools in the Motheo district, Bloemfontein city, from which the researchers identified $2 \mathrm{I}$ schools with grade pre- $R$ and/or grade $\mathrm{R}$ classes, with more than 30 children in the school. However, according to the "school finder" search, not all of these schools were ALOLT schools. From the list of 21 schools, only 12 were identified as ALOLT schools with more than 30 learners, and represented quintile 3, 4, and 5 schools. These 12 schools were contacted telephonically and by email, informed about the study and invited to participate.

Of the 12 schools, four schools were eligible to be included in the study. The remaining schools either did not agree to participate, were not suitable (e.g., did not have a Grade R or pre-R class), had insufficient contact details, or did not respond to phone calls and emails after several attempts to contact them. Written informed consent was obtained from the principals and the teachers involved at the eligible schools prior to the study.

The four participating schools were contacted to obtain information with regard to the number of Grade pre- $R$ and Grade $R$ classes they had, how many children there were, how many per gender, and how many of the children in these classes were between the ages of 5 years 6 months and 5 years II months. Ninety potential children were identified using a convenience sampling method.

The parents/guardians of these 90 children received information letters and parent questionnaires. Sixty-three of these questionnaires were completed and returned on time, giving a response rate of $70 \%$. However, two of these children did not meet the inclusion/exclusion criteria, one child did not complete the assessment, one child did not assent to participate, and seven children were absent during data collection, giving a total of 52 children who participated in the study. The same inclusion and exclusion criteria used in the ELOLT study ${ }^{7}$ were applied to ensure comparability to the previous study.

Children were included in the ALOLT study if they were aged between 5 years 6 months and 5 years II months of age, attended an ALOLT school since January 2016, and were able to speak and understand Afrikaans. Children were excluded from the study if any of the following aspects were indicated on the parent/caregiver questionnaire:

* the child had physical and/or cognitive disabilities or limitations due to a pathology that could negatively influence their participation during the tests;

* the child presented with any sensory, physical or emotional impairment or any condition that could influence their participation and/or test results;

* the child had been tested by means of the three tests within the preceding six months before the research was conducted;

* the child had received occupational therapy intervention or any other type of therapy, such as seeing a psychologist, before the study;

* the parents/guardians did not give consent for the child's participation in the study; and

* the child did not assent to participate.

\section{Data collection}

Prior to the study, the prescribed instructions of the three tests were translated into Afrikaans. The student researchers who collected the data had theoretical and clinical training in the use of all three of the assessment instruments. Furthermore, the first author had a workshop with the student researchers to revise the prescribed instructions (translated in Afrikaans), scorings of the tests, and other logistic matters.

The principal researcher visited the four schools to make arrangements with the school and/or class teacher regarding the venue, date and time of data collection and timetable, and rescheduling of learning activities for the duration of the data collection. All arrangements were confirmed telephonically one day prior to data collection.

A pilot study was done on two children at one of the participating schools using the prescribed guidelines of each test, in order to orientate the researchers and teachers to the research process and 
Table I: Summary of the characteristics and measurement properties of the Beery-Buktenica Developmental Test of Visual-motor Integration $6^{\text {th }}$ edition (Beery VMI-6) ${ }^{4}$, Development Test of Visual Perception $3^{\text {rd }}$ edition (DTVP-3) ${ }^{5}$ and Test of Visual Perceptual Skills $3^{\text {rd }}$ edition (TVPS-3) ${ }^{6}$

\begin{tabular}{|c|c|c|c|}
\hline Details & Beery VMI-6 & DTVP-3 & TVPS-3 \\
\hline Authors & Beery and Beery ${ }^{4}$ & Hammil, Pearson and Vores ${ }^{5}$ & Martin $^{6}$ \\
\hline Year published & 2010 & 2014 & 2006 \\
\hline Country & United States & United States & United States \\
\hline Language of publication & English & English & English \\
\hline Age range & $2-100$ years of age & $4-12$ years of age & $4-18$ years of age \\
\hline $\begin{array}{l}\text { Sample size } \\
\text { (norming group) }\end{array}$ & $\begin{array}{l}\text { I737 children/youth }(1-18 \text { years }) \\
\text { and } 1021 \text { adults (> } 19 \text { years) }\end{array}$ & 1035 children (4-12 years) & 2008 children (4-18 years) \\
\hline Time to administer & $15-20$ minutes & 20-30 minutes & Approximately 30 minutes \\
\hline Prefabricated equipment/material & $\begin{array}{l}\text { Yes, consists of manual, picture } \\
\text { book and record forms }\end{array}$ & $\begin{array}{l}\text { Yes, consists of manual, picture } \\
\text { book and record forms }\end{array}$ & $\begin{array}{l}\text { Yes, consists of manual, picture book } \\
\text { and record forms }\end{array}$ \\
\hline Availability & Yes & Yes & Yes \\
\hline Public domain & Yes & Yes & Yes \\
\hline \multicolumn{4}{|l|}{ Costs } \\
\hline Instructions & $\begin{array}{l}\text { Published administration, scoring } \\
\text { and interpretation }\end{array}$ & $\begin{array}{l}\text { Published administration, } \\
\text { scoring and interpretation }\end{array}$ & $\begin{array}{l}\text { Published administration, scoring } \\
\text { and interpretation }\end{array}$ \\
\hline Tester training & Minimal & Minimal & Minimal \\
\hline Sub-tests (subscales) & $\begin{array}{l}\text { Visual-motor integration (VMI), } \\
\text { motor coordination (MC) and } \\
\text { visual perception (VP) }\end{array}$ & $\begin{array}{l}\text { Eye-hand coordination (EH), } \\
\text { copying (CO), figure-ground } \\
\text { (FG), visual closure (VC) and } \\
\text { form constancy (FC) }\end{array}$ & $\begin{array}{l}\text { Visual discrimination (VD), visual } \\
\text { memory (VM), spatial relations (SR), } \\
\text { form constancy (FC), sequential } \\
\text { memory (SM), figure-ground (FG) } \\
\text { and visual closure (VC) }\end{array}$ \\
\hline $\begin{array}{l}\text { Internal consistency (Cronbach's } \\
\text { alpha) }\end{array}$ & VMI: 0.88; VP: 0.85; MC: 0.87 & $\begin{array}{l}\text { EH: } 0.90 ; \text { CO: } 0.85 ; \text { FG: } 0.90 ; \\
\text { VC: } 0.80 ; \text { FC: } 0.86 ; \text { GVP: } 0.95 ; \\
\text { MRVP: } 0.92 \text {; VMI: } 0.92\end{array}$ & $\begin{array}{l}\text { VD: 0.76; VM: 0.76; SR: 0.87; FC: } \\
\text { 0.75; SM: 0.78; FG: 0.82; VC: } 0.82\end{array}$ \\
\hline $\begin{array}{l}\text { Test re-test reliability (Pearson } \mathrm{R} \\
\text { correlation) }\end{array}$ & VMI: 0.88; VP: 0.84; MC: 0.85 & $\begin{array}{l}\text { Sub-test: } 0.70-0.85 \\
\text { Total composite scores: } \\
0.87-0.90\end{array}$ & $\begin{array}{l}\text { Ranges from } 0.34 \text { to } 0.8 \mathrm{I} \text { for sub- } \\
\text { test } \\
\text { Test as a whole } 0.97\end{array}$ \\
\hline $\begin{array}{l}\text { Inter-rater reliability (Pearson } \mathrm{R} \\
\text { correlation) }\end{array}$ & VMI: 0.93; VP: 0.98; MC: 0.94 & 0.90 & Not indicated \\
\hline $\begin{array}{l}\text { Criterion validity - concurrent } \\
\text { validity (Pearson R correlation) }\end{array}$ & $\begin{array}{l}\text { VMI: } 0.52 \text { (WRAVMA drawing } \\
\text { test); } 0.75 \text { (DTVP-2 copying } \\
\text { subscale) } \\
\text { VP: } 0.62 \text { (DTVP-2 position in } \\
\text { space subscale) } \\
\text { MC: } 0.65 \text { (DTVP-2 eye-hand } \\
\text { coordination subscale) }\end{array}$ & $\begin{array}{l}\text { Eye-hand coordination: } 0.73 \\
\text { (Beery VMI-5) } \\
\text { Copying: } 0.72 \text { (Beery VMI-5) } \\
\text { Form constancy: } 0.65 \text { (TVPS-3) } \\
\text { Visual closure: } 0.76 \text { (TVPS-3) } \\
\text { Form constancy: } 0.7 \text { I (TVPS-3) } \\
\text { General visual perception: } 0.74 \\
\text { (Beery VMI-5); } 0.78 \text { (TVPS-3) } \\
\text { Motor reduced visual } \\
\text { perception: } 0.8 \mathrm{I} \text { (TVPS-3) } \\
\text { VMI: } 0.8 \mathrm{I} \text { (Beery VMI-5) }\end{array}$ & $\begin{array}{l}\text { TVPS-3: } 0.50 \text { (Beery VMI-5 total) } \\
\text { TVPS-3: } 0.67 \text { (Beery VMI-5 visual } \\
\text { subscale) }\end{array}$ \\
\hline Characteristics & $\begin{array}{l}\text { Three sub-tests, the first one } \\
\text { requires the individual to copies } \\
\text { a series of geometric forms } \\
\text { into a response booklet. In the } \\
\text { second sub-test, the individual } \\
\text { selects the geometric form that } \\
\text { is the same as the stimulus within } \\
\text { two minutes. The third sub-test } \\
\text { requires the individual to trace } \\
\text { between the lines of geometric } \\
\text { forms within three minutes. }\end{array}$ & $\begin{array}{l}\text { Five sub-tests of which two } \\
\text { sub-tests require the individual } \\
\text { to copy or trace forms in } \\
\text { a response booklet. Three } \\
\text { sub-tests involve the individual } \\
\text { selecting the correct answer. }\end{array}$ & $\begin{array}{l}\text { Seven sub-tests with two example } \\
\text { items and } 16 \text { assessment items. }\end{array}$ \\
\hline
\end{tabular}


Table II: Published research on the Beery VMI-6, DTVP-3 and TVPS-3 available during the study, excluding studies involving specific diagnoses such as Down syndrome and autism

\begin{tabular}{|c|c|c|}
\hline Beery VMI-6 & DTVP-3 & TVPS-3 \\
\hline $\begin{array}{l}\text { Fang Y, Wang J, Zhang Y and Qin J. The } \\
\text { relationship of motor coordination, visual } \\
\text { perception, and executive function to the } \\
\text { development of 4-6-year-old Chinese pre- } \\
\text { schoolers' visual-motor integration skills. } \\
\text { BioMed Research International. 2017; 20I 7: } \\
6264254^{15} \text {. }\end{array}$ & $\begin{array}{l}\text { Brown T. Validity and reliability of the } \\
\text { Developmental Test of Visual Perception } \\
\text { - Third Edition. Occupational Therapy in } \\
\text { Health Care. 2016; 30: } 272-288^{14} \text {. }\end{array}$ & $\begin{array}{l}\text { Chiu E, Wu W, Chou C, Yu M and Hung J. } \\
\text { Test-retest reliability and minimal detectable } \\
\text { change of the Test of Visual Perceptual Skills } \\
\text { Third Edition in patients with stroke. Archives } \\
\text { of Physical Medicine and Rehabilitation. 2016; } \\
\text { 97: } 1917-1923^{16} \text {. }\end{array}$ \\
\hline $\begin{array}{l}\text { Harvey EM, Leonard-Green TK, Mohan KM, } \\
\text { Kulp MT, Davis AL, Miller JM, Twelker JD, } \\
\text { Campus I and Dennis LK. Interrater and test- } \\
\text { retest reliability of the Beery Visual-Motor } \\
\text { Integration in schoolchildren. Optometry And } \\
\text { Vision Science, } 2017 ; 94: 598-605^{30} \text {. }\end{array}$ & $\begin{array}{l}\text { Brown T and Murdolo Y. The Developmental } \\
\text { Test of Visual Perception-Third Edition } \\
\text { (DTVP-3): a review, critique, and practice } \\
\text { implications. Journal of Occupational Therapy, } \\
\text { Schools and Early Intervention. 20 I5; 8: } \\
336-354^{12} \text {. }\end{array}$ & $\begin{array}{l}\text { Brown T, Mullins E and Stagnitti K. The } \\
\text { concurrent validity of three visual perception } \\
\text { tests used with adults. Occupational Therapy } \\
\text { in Health Care, 2009; 23: 99-II } 18^{31} \text {. }\end{array}$ \\
\hline $\begin{array}{l}\text { McDonald CA, Volker MA, Lopata C, Toomey } \\
\text { JA, Thomeer ML, Lee GK, Lipinski AM, } \\
\text { Dua EH, Schiavo AM, Bain F and Nelson } \\
\text { AT. VMI-VI and BG-II KOPPITZ-2 for youth } \\
\text { with HFASDs and typical youth. Journal of } \\
\text { Psychoeducational Assessment, 20I4; 32: } \\
379-389^{27} \text {. }\end{array}$ & $\begin{array}{l}\text { Clarke K. Construct validity of the } \\
\text { Developmental Test of Visual-Perception } \\
\text { Third Edition (DTVP-3) in Western Australian } \\
\text { primary school children. 20I5. http://ro.ecu. } \\
\text { edu.au/theses_hons/I474 (accessed I2 April } \\
2018)^{8} \text {. }\end{array}$ & $\begin{array}{l}\text { Brown T, Bourne R, Sutton E, Wigg S, Burgess } \\
\text { D, Glass S, Elliott S and Lalor A. The reliability } \\
\text { of three visual perception tests used to assess } \\
\text { adults. Perceptual Motor Skills. 20 I 0; I I I: } \\
45-59^{9} \text {. }\end{array}$ \\
\hline $\begin{array}{l}\text { Ho W, Tang MM, Fu C, Leung K, Pang PC and } \\
\text { Cheong AM. Relationship between vision and } \\
\text { visual perception in Hong Kong pre-schoolers. } \\
\text { Optometry and Vision Science, 20 I5; 92: } \\
623-63 \mathrm{I}^{17} \text {. }\end{array}$ & $\begin{array}{l}\text { Brown T and Link J. The association between } \\
\text { measures of visual perception, visual-motor } \\
\text { integration, and in-hand manipulation skills } \\
\text { of school-age children and their manuscript } \\
\text { handwriting speed. British Journal of } \\
\text { Occupational Therapy. 2015; 79: } 163-\left.17\right|^{13} \text {. }\end{array}$ & $\begin{array}{l}\text { Brown T. Validity and reliability of the } \\
\text { Developmental Test of Visual Perception } \\
\text { - Third Edition. Occupational Therapy in } \\
\text { Health Care. 2016; 30: } 272-288^{14} \text {. }\end{array}$ \\
\hline $\begin{array}{l}\text { Brown T and Link J. The association between } \\
\text { measures of visual perception, visual-motor } \\
\text { integration, and in-hand manipulation skills } \\
\text { of school-age children and their manuscript } \\
\text { handwriting speed. British Journal of } \\
\text { Occupational Therapy. } 2015 ; 79: 163-\left.17\right|^{13} \text {. }\end{array}$ & $\begin{array}{l}\text { Visser MM, Nel M, Jansen T, Kinmont L, } \\
\text { Terblanché S and Van Wyk J. Visual perception } \\
\text { of five-year-old, English-speaking children } \\
\text { in Bloemfontein using the Beery 6 } 6^{\text {th }} \text {, DTVP- } \\
3 \text {, and TVPS-3. South African Journal of } \\
\text { Occupational Therapy. } 2017 ; 47: 17-26^{7} \text {. }\end{array}$ & $\begin{array}{l}\text { Brown T, Elliot S, Bourne R, Sutton E, } \\
\text { Wigg S, Morgan D, Glass S and Lalor A. } \\
\text { The discriminative validity of three visual } \\
\text { perceptual tests. New Zealand Journal of } \\
\text { Occupational Therapy. 20I I; 58: I4-22'". }\end{array}$ \\
\hline $\begin{array}{l}\text { Visser MM, Nel M, Jansen T, Kinmont L, } \\
\text { Terblanché S and Van Wyk J. Visual perception } \\
\text { of five-year-old, English-speaking children } \\
\text { in Bloemfontein using the Beery } 6^{\text {th }} \text {, DTVP- } \\
3 \text {, and TVPS-3. South African Journal of } \\
\text { Occupational Therapy. } 2017 ; 47: 17-26^{7} \text {. }\end{array}$ & $\begin{array}{l}\text { Harris M. The validity of standardized visual } \\
\text { perceptual tests in identifying specific learning } \\
\text { disabilities in children from Gauteng Province, } \\
\text { South Africa. Presentation at the } 35^{\text {th }} \\
\text { Occupational Therapy Association (OTASA) } \\
\text { Congress, WITS University Johannesburg, } \\
14-16 \text { July } 2016^{19} \text {. }\end{array}$ & $\begin{array}{l}\text { Brown T, Mullins E and Stagnitti K. The } \\
\text { reliability of performance of healthy adults on } \\
\text { three visual perception tests. British Journal of } \\
\text { Occupational Therapy, 2008; } 71: 438-47^{31} \text {. }\end{array}$ \\
\hline \multirow[t]{3}{*}{$\begin{array}{l}\text { Harris M. The validity of standardized visual } \\
\text { perceptual tests in identifying specific learning } \\
\text { disabilities in children from Gauteng Province, } \\
\text { South Africa. Presentation at the } 35^{\text {th }} \\
\text { Occupational Therapy Association (OTASA) } \\
\text { Congress, WITS University Johannesburg, } \\
\text { 14-16 July } 2016^{19} \text {. }\end{array}$} & & $\begin{array}{l}\text { Ho W, Tang MM, Fu C, Leung K, Pang PC and } \\
\text { Cheong AM. Relationship between vision and } \\
\text { visual perception in Hong Kong pre-schoolers. } \\
\text { Optometry and Vision Science, 20 I 5; 92: } \\
623-631^{17} \text {. }\end{array}$ \\
\hline & & $\begin{array}{l}\text { Visser MM, Nel M, Jansen T, Kinmont L, } \\
\text { Terblanché S and Van Wyk J. Visual perception } \\
\text { of five-year-old, English-speaking children } \\
\text { in Bloemfontein using the Beery } 6^{\text {th }} \text {, DTVP- } \\
3 \text {, and TVPS-3. South African Journal of } \\
\text { Occupational Therapy. } 2017 ; 47: 17-26^{7} \text {. }\end{array}$ \\
\hline & & $\begin{array}{l}\text { Harris M. The validity of standardized visual } \\
\text { perceptual tests in identifying specific learning } \\
\text { disabilities in children from Gauteng Province, } \\
\text { South Africa. Presentation at the } 35^{\text {th }} \\
\text { Occupational Therapy Association (OTASA) } \\
\text { Congress, WITS University Johannesburg, } \\
\text { 14-16 July } 2016^{19} \text {. }\end{array}$ \\
\hline
\end{tabular}


to refine the Afrikaans instructions if needed. Since no adjustments to the administration of the tests were required, the data collected from the pilot study were included in the results of the main study.

Six trained student researchers were assigned per school per day, and assessed two to three children individually per day for two consecutive days. The allocated venue was prepared to ensure minimal distractions and equipped with age-appropriate tables and chairs. To ensure consistency of the testing environment, the researchers had to take age-appropriate tables and chairs to some of the schools that could not provide them for the research study.

After assent, the researchers ensured that the child had eaten breakfast or a snack prior to testing and was feeling well.

To enhance reliability and ensure comparability to the previous study, the three tests were administered in the same order and according to the translated prescribed method of each instrument's Examiner's Manual ${ }^{4-6}$. The TVPS- 3 was administered first, after which the child received approximately an hour break. The researcher collected the second child from the class and assessed the child on the TVPS-3 (followed by an hour break). During the hour break of the second child, the researcher assessed the first child on the DTVP-3. A short break was provided after the administration of the DTVP-3 and the administration of the Beery VMI-6 followed. Finally, the second child was also assessed on the DTVP-3 and Beery VMI-6.

Scoring of the tests was completed after the child had been assessed, by using each instrument's Examiner's Manual ${ }^{4-6}$. To prevent possible errors during data capturing, the scoring of the three tests were verified by two researchers (each making sure she did not conduct the test being verified) before the data were transferred to the score sheets. All errors in transferring scores to the data form were checked and corrected by going back to the original testing forms. Furthermore, the data on the score sheets were verified before analysis.

\section{Data analysis}

Descriptive statistics, namely frequencies and percentages for categorical data and medians and percentiles for continuous data, were calculated for each sub-test for gender and language, and compared by means of $95 \%$ confidence intervals $(95 \% \mathrm{Cl})$ for the median differences.

\section{Ethical considerations}

Approval for this follow-up study was obtained from the Health Science Research Ethics Committee of the Faculty of Health Sciences, University of the Free State (reference HSREC-S I5/20I6). To ensure ethical conduct, written permission was received from the Director of Strategic Planning, Policy and Research, Free State Department of Basic Education, the participating schools' principals and class teachers. Informed consent was obtained from all the parents/guardians of the participating children and assent from the children was obtained prior to the study.

To adhere to copyright principles of the publishing companies, the original test booklets were used for all children. An information letter was sent to the three publishers of the three tests in order to obtain permission for research and translation of instructions.

For parents/guardians who requested to be informed if their child scored below average in all three tests, a letter containing a summary of the child's performance on the tests, as well as Occupational Therapy Association of South Africa's (OTASA) contact details (where contact details of OTs in their area could be located) was sent.

\section{RESULTS AND DISCUSSION}

\section{Demographic information}

Four schools were included in the study and slightly more than half of the children were in Grade pre-R $(51.9 \%$ versus $48.1 \%$ of children in Grade R). Approximately a third of the sample $(n=52)$ was from school C (30.8\%), followed by school D $(25 \%)$, school A (23.1\%), and school B (2I.1\%). Most of the children were girls $(n=32 ; 61.5 \%)$. The sample consisted of 45 (86.5\%) white, two (3.9\%) coloured and five ( $9.6 \%$ ) black Afrikaans-speaking children . The median age was 5 years 7 months, ranging between 5 years 6 months and 5 years 11 months. The median time of school attendance was 2 years and 7 months (range 0.7-5.7 years).

\section{Beery VMI-6}

Table III (page 36) indicates that for all the sub-tests of the Beery VMI-6, the English- and Afrikaans-speaking children scored below the American standard score (SS) norm of 100 , but within the normative range of 85 to $115^{6}$. The English- and Afrikaans-speaking children performed the best in the motor coordination sub-test (both groups SS 98), followed by the visual-motor integration (SS 96 and 97.5 , respectively) and the visual perception (SS 92 and 96 , respectively) sub-tests.

In another study by Rens ${ }^{32}$, it was found that South African children in the Eastern Cape Province obtained significantly lower visual-motor integration and visual perceptual scores than the American norms This might however because they were mostly from very low socio-economic groups, and according to Buktenica ${ }^{33}$, the Beery is sensitive in predicting achievement in socio-economic groups, as reflected by Rens's findings ${ }^{32}$.

Conversely, slightly higher mean standard scores have been reported by Fang et al. ${ }^{15}$, for Chinese children aged four, five and six years for visual-motor integration (SS I07.58, II 2.38 and I05.80, respectively), motor coordination (SS 103.82, I09.6I and 108.37, respectively) and visual perception (SS I I I.53, I I 7.70 and I I 5.07, respectively) ${ }^{15}$. Higher mean visual-motor integration scaled scores were also noted in American children (105.17 $)^{34}$, in children from Singapore (SS between I I 3.7 and 120.7 ) 22 and in some South African children (SS 96) ${ }^{19}$. Higher scores on motor coordination were obtained by a South African sample ${ }^{35}$.

Both the English- and Afrikaans-speaking children obtained scores similar to the American children with regard to consistency between sub-test standard scores. In other words, there were no major differences between the SS scores of the sub-tests on motor coordination, visual-motor integration and visual perception (English SS 98, 96, 92, respectively and Afrikaans SS 98, 97.5, 93, respectively). These findings were similar to studies conducted in Canada $^{36}$ and China ${ }^{15}$.

When comparing the gender scores of the sub-tests, a statistically significant difference was found in the motor coordination sub-test of the English-speaking children, with girls performing better. This finding was comparable to other studies where better performance was noticed among girls on the visual-motor integration sub-test ${ }^{23,36,37}$. However, in the study on Afrikaans-speaking children, boys and girls scored the same (both SS 98) on the motor coordination sub-test. No statistically significant differences between genders on any other sub-tests were found.

When comparing the two language groups' results of the composite Beery VMI-6 scores, no statistically significant differences were evident, as seen in Table III (page 36). In a study that compared English- and Chinese-speaking children ${ }^{38}$, significant differences in visual perceptual skills between the two language groups were reported. However, no others studies could be found to either corroborate or contradict language as a predictive variable that could play a role in visual perceptual skills.

Based on both the ELOLT and ALOLT studies' findings, the Beery VMI-6 appears to be a suitable initial measure in an assessment battery for both samples of South African children, with no extreme cultural, gender or language bias found in any of the subtests $^{39}$. This instrument also provides clinicians and researchers with a good measurement instrument that can establish a variety of visual, perceptual and motor abilities in children. Furthermore, the enjoyment and feelings of success experienced by the children through drawing, can contribute to establish rapport ${ }^{40}$.

\section{DTVP-3}

Table IV (page 37) summarises the median scaled scores obtained 
Table III(a): The Beery VMI-6 sub-tests, overall scores and comparison of gender differences per language group

\begin{tabular}{|c|c|c|c|c|c|c|c|c|c|c|c|c|}
\hline \multicolumn{13}{|l|}{ ENGLISH } \\
\hline \multirow{4}{*}{ Sub-test } & \multicolumn{9}{|c|}{ Median (range) } & \multirow{2}{*}{\multicolumn{3}{|c|}{$\begin{array}{l}95 \% \mathrm{Cl}^{*} \text { (median } \\
\text { difference for gender) }\end{array}$}} \\
\hline & \multicolumn{3}{|c|}{ Total group $(n=68)$} & \multicolumn{3}{|c|}{ Girls $(n=40)$} & \multicolumn{3}{|c|}{ Boys $(n=28)$} & & & \\
\hline & \multicolumn{3}{|c|}{ Score } & \multicolumn{3}{|c|}{ Score } & \multicolumn{3}{|c|}{ Score } & \multicolumn{3}{|c|}{ Score } \\
\hline & Raw & Standard & Scaled & Raw & Standard & Scaled & Raw & Standard & Scaled & Raw & Standard & Scaled \\
\hline \multirow{2}{*}{$\begin{array}{l}\text { Motor } \\
\text { coordination } \\
\text { (MC) }\end{array}$} & 16 & 98 & 10 & 17 & 103.5 & 10.5 & 15 & 94 & 9 & {$[1 ; 3]^{*}$} & {$[3 ; 12]^{*}$} & {$[0 ; 2]$} \\
\hline & $(\mathrm{II}-24)$ & $(76-133)$ & $(5-17)$ & $(13-24)$ & $(86-133)$ & $(7-17)$ & $(\mathrm{II}-22)$ & $(76-123)$ & $(5-15)$ & & & \\
\hline \multirow{2}{*}{$\begin{array}{l}\text { Visual- } \\
\text { motor } \\
\text { integration } \\
\text { (VMI) }\end{array}$} & 15 & 96 & 9 & 15 & 96 & 9 & 15 & 96.5 & 9 & {$[-I ; I]$} & {$[-4 ; 4]$} & {$[-I ; I]$} \\
\hline & $(9-2 I)$ & $(72-121)$ & $(4-14)$ & $(9-2 I)$ & $(72-12 I)$ & $(4-14)$ & $(10-19)$ & $(75-114)$ & $(5-13)$ & & & \\
\hline \multirow{2}{*}{$\begin{array}{l}\text { Visual } \\
\text { perception } \\
\text { (VP) }\end{array}$} & 15 & 92 & 8 & 15 & 92 & 8 & 15 & 92 & 8 & {$[-2 ; 1]$} & {$[-10 ; 4]$} & {$[-2 ; I]$} \\
\hline & $(6-26)$ & $(45-136)$ & $(-I-17)$ & $(6-26)$ & $(45-136)$ & $(-1-17)$ & $(\mathrm{II}-22)$ & $(75-120)$ & $(5-14)$ & & & \\
\hline \multirow[t]{2}{*}{ Overall } & & 97.2 & & & 97.7 & & & 96 & & & {$[-3.3 ; 5]$} & \\
\hline & & $(73-121)$ & & & $(73-121)$ & & & $(79.7-107.3)$ & & & & \\
\hline \multicolumn{13}{|l|}{ AFRIKAANS } \\
\hline \multirow{4}{*}{ Sub-test } & \multicolumn{9}{|c|}{ Median (range) } & \multirow{2}{*}{\multicolumn{3}{|c|}{$\begin{array}{c}95 \% \mathrm{Cl}^{*} \text { (median } \\
\text { difference for gender) }\end{array}$}} \\
\hline & \multicolumn{3}{|c|}{ Total group $(n=52)$} & \multicolumn{3}{|c|}{ Girls $(n=32)$} & \multicolumn{3}{|c|}{ Boys $(n=20)$} & & & \\
\hline & \multicolumn{3}{|c|}{ Score } & \multicolumn{3}{|c|}{ Score } & \multicolumn{3}{|c|}{ Score } & \multicolumn{3}{|c|}{ Score } \\
\hline & Raw & Standard & Scaled & Raw & Standard & Scaled & Raw & Standard & Scaled & Raw & Standard & Scaled \\
\hline \multirow{2}{*}{$\begin{array}{l}\text { Motor } \\
\text { coordination } \\
\text { (MC) }\end{array}$} & 16 & 98 & 10 & 16 & 98 & 10 & 16 & 98 & 10 & {$[-1 ; 2]$} & {$[-4 ; 8]$} & {$[-1 ; 1]$} \\
\hline & $(10-25)$ & $(7 \mid-135)$ & $(5-17)$ & $(10-25)$ & $(7 \mid-135)$ & $(4-17)$ & $(\mathrm{II}-20)$ & $(80-113)$ & $(6-13)$ & & & \\
\hline \multirow{2}{*}{$\begin{array}{l}\text { Visual- } \\
\text { motor } \\
\text { integration } \\
\text { (VMI) }\end{array}$} & 15 & 97.5 & 9.5 & 15 & 97 & 9 & 15 & 98 & 10 & {$[-1 ; I]$} & {$[-4 ; 5]$} & {$[-I ; I]$} \\
\hline & $(\mathrm{II}-23)$ & $(80-132)$ & $(6-16)$ & $(\mathrm{II}-23)$ & $(80-132)$ & $(6-16)$ & $(12-19)$ & $(87-I \mid 2)$ & $(7-12)$ & & & \\
\hline \multirow{2}{*}{$\begin{array}{l}\text { Visual } \\
\text { perception } \\
\text { (VP) }\end{array}$} & 15 & 93 & 8.5 & 16 & 98 & 10 & 15 & 92 & 8 & {$[-1 ; 3]$} & {$[-4 ; 11]$} & {$[0 ; 2]$} \\
\hline & $(8-24)$ & $(56-127)$ & $(I-15)$ & $(8-24)$ & $(56-127)$ & $(1-15)$ & $(8-19)$ & $(56-107)$ & $(I-I I)$ & & & \\
\hline \multirow[t]{2}{*}{ Overall } & & 96 & & & 96.5 & & & 96 & & & {$[-3 ; 7]$} & \\
\hline & & $(55-123)$ & & & $(78-123)$ & & & $(55-108)$ & & & & \\
\hline
\end{tabular}

Table III(b): Comparison of $95 \% \mathrm{Cl}$ for the median difference between English- and Afrikaans-speaking groups

\begin{tabular}{|l|c|c|c|}
\hline \multirow{2}{*}{ Sub-test } & \multicolumn{3}{|c|}{$95 \%$ Cl } \\
\cline { 2 - 4 } & \multicolumn{3}{|c|}{ Score } \\
\cline { 2 - 4 } & Raw & Standard & Scaled \\
\hline Motor coordination (MC) & {$[0 ; 2]$} & {$[-1 ; 5]$} & {$[0 ; 1]$} \\
\hline Visual-motor integration (VMI) & {$[-1 ; 1]$} & {$[-3 ; 2]$} & {$[-1 ; 0]$} \\
\hline Visual perception (VP) & {$[-I ; I]$} & {$[-4 ; 4]$} & {$[-I ; I]$} \\
\hline Overall & & {$[-2.3 ; 4.0]$} & \\
\hline
\end{tabular}

by English- and Afrikaans-speaking children for all the sub-tests, as compared to the American normative scaled score of 10 for all these sub-tests and a normative range of 7 to $13^{5}$. The authors would like to note that although studies have been conducted on the DTVP-3, $3^{8,12,13}$, they all had different aims, and most of these studies did not provide descriptive data (including sub-test raw- and scale scores as presented in the manuals). Consequently, results could only be compared with two other studies ${ }^{19,24}$ and the research on the DTVP-2 version of the test reported previously ${ }^{24}$.

For the eye-hand coordination sub-test in the DTVP-3, the
English- and Afrikaans-speaking children performed the same (both SS 9), but with lower normative median scaled score as compared to the American norm. It was, however, consistent with findings by Harris ${ }^{19}$ who reported a scaled score of 8.7 for South African children aged 6-9 years on the DTVP-3. The eye-hand coordination subscale requires a child to draw a continuous line within a narrow range, which may be more challenging for five-year-old children as compared to older school going children, who have likely been exposed to precision tasks at school for a number of years ${ }^{14}$.

The results on the copying sub-tests (SS 10 and II.5, respec- 
Table IV(a): The DTVP-3 sub-tests, composite scores and comparison of gender differences per language group

\begin{tabular}{|c|c|c|c|c|c|c|c|c|}
\hline \multicolumn{9}{|l|}{ ENGLISH } \\
\hline \multirow{3}{*}{ Sub-test } & \multicolumn{6}{|c|}{ Median (range) } & \multirow{3}{*}{\multicolumn{2}{|c|}{$\begin{array}{c}95 \% \mathrm{Cl} \text { (median difference } \\
\text { for gender) }\end{array}$}} \\
\hline & \multicolumn{2}{|c|}{ Total group $(n=68)$} & \multicolumn{2}{|c|}{ Girls $(n=40)$} & \multicolumn{2}{|c|}{ Boys $(n=28)$} & & \\
\hline & Raw & Scaled & Raw & Scaled & Raw & Scaled & & \\
\hline \multirow{2}{*}{$\begin{array}{l}\text { Eye-hand } \\
\text { coordination(EH) }\end{array}$} & 145.5 & 9 & 145.5 & 9 & 145.5 & 9 & {$[-13 ; 9]$} & {$[-2 ; 1]$} \\
\hline & $(82-180)$ & $(3-14)$ & $(82-178)$ & $(3-14)$ & $(113-180)$ & $(6-14)$ & & \\
\hline \multirow[t]{2}{*}{ Copying (CO) } & 18 & 10 & 18.5 & 10 & 18 & 10 & {$[-1 ; 5]$} & {$[0 ; 3]$} \\
\hline & $(8-117)$ & $(5-19)$ & $(8-117)$ & $(5-19)$ & $(9-31)$ & $(5-18)$ & & \\
\hline \multirow[t]{2}{*}{ Figure-ground (FG) } & 33 & 8 & 31.5 & 8 & 34 & 8 & {$[-4 ; 7]$} & {$[-I ; 2]$} \\
\hline & $(6-54)$ & $(2-14)$ & $(17-54)$ & $(4-14)$ & $(6-49)$ & $(2-13)$ & & \\
\hline \multirow[t]{2}{*}{ Visual closure (VC) } & 7 & 7.5 & 6.5 & 7 & 8 & 8.5 & {$[-2 ; 0]$} & {$[-2 ; 0]$} \\
\hline & $(2-14)$ & $(3-13)$ & $(2-14)$ & $(3-13)$ & $(3-14)$ & $(4-13)$ & & \\
\hline \multirow{2}{*}{$\begin{array}{l}\text { Form constancy } \\
\text { (FC) }\end{array}$} & 28 & 8.5 & 28.5 & 9 & 28 & 8 & {$[-2 ; 4]$} & {$[-I ; 2]$} \\
\hline & $(17-40)$ & $(3-18)$ & $(21-40)$ & $(5-18)$ & $(17-36)$ & $(3-13)$ & & \\
\hline $\begin{array}{l}\text { DTVP-3 } \\
\text { composite scores } \\
\text { (Comp: composite) }\end{array}$ & Comp & $\begin{array}{l}\text { Sum of } \\
\text { scaled }\end{array}$ & Comp & $\begin{array}{l}\text { Sum of } \\
\text { scaled }\end{array}$ & Comp & $\begin{array}{l}\text { Sum of } \\
\text { scaled }\end{array}$ & Comp & Scaled \\
\hline \multirow{2}{*}{$\begin{array}{l}\text { Visual motor } \\
\text { integration (VMI) }\end{array}$} & 98.5 & 20 & 98.5 & 19.5 & 98.5 & 20 & {$[-3 ; 9]$} & {$[-2 ; 3]$} \\
\hline & $(76-127)$ & $(12-29)$ & $(82-127)$ & $(14-29)$ & $(76-118)$ & $(12-27)$ & & \\
\hline \multirow{2}{*}{$\begin{array}{l}\text { Motor-reduced } \\
\text { visual perception } \\
\text { (MRP) }\end{array}$} & 88 & 24 & 89 & 24.5 & 86 & 23 & {$[-4 ; 7]$} & {$[-2 ; 4]$} \\
\hline & $(67-116)$ & $(14-38)$ & $(67-116)$ & $(14-38)$ & $(67-108)$ & $(14-34)$ & & \\
\hline \multirow{2}{*}{$\begin{array}{l}\text { General visual } \\
\text { perception (GVP) }\end{array}$} & 93 & 44 & 95 & 46 & 91 & 43 & {$[-3 ; 6]$} & {$[-3 ; 6]$} \\
\hline & $(76-116)$ & $(31-62)$ & $(78-116)$ & $(32-62)$ & $(76-I I 2)$ & $(31-59)$ & & \\
\hline \multicolumn{9}{|l|}{ AFRIKAANS } \\
\hline \multirow{3}{*}{ Sub-test } & \multicolumn{6}{|c|}{ Median (range) } & \multirow{3}{*}{\multicolumn{2}{|c|}{$\begin{array}{c}95 \% \mathrm{Cl} \text { (median difference } \\
\text { for gender) }\end{array}$}} \\
\hline & \multicolumn{2}{|c|}{ Total group $(n=52)$} & \multicolumn{2}{|c|}{ Girls $(n=32)$} & \multicolumn{2}{|c|}{ Boys $(n=28)$} & & \\
\hline & Raw & Scaled & Raw & Scaled & Raw & Scaled & & \\
\hline \multirow{2}{*}{$\begin{array}{l}\text { Eye-hand } \\
\text { coordination(EH) }\end{array}$} & 143 & 9 & 143 & 9 & 142.5 & 9 & {$[-12 ; 10]$} & {$[-I ; I]$} \\
\hline & $(65-177)$ & $(2-14)$ & $(65-177)$ & $(2-14)$ & $(105-166)$ & $(6-11)$ & & \\
\hline Copying (CO) & 19.5 & 11.5 & 20 & 12 & 18.5 & 10.5 & {$[-3 ; 4]$} & {$[-1 ; 2]$} \\
\hline & $(8-32)$ & $(5-19)$ & $(8-32)$ & $(5-19)$ & $(9-30)$ & $(5-18)$ & & \\
\hline Figure-ground (FG) & 34 & 8.5 & 30 & 7.5 & 34.5 & 9 & {$[-11 ; 3]$} & {$[-3 ; I]$} \\
\hline & $(12-55)$ & $(4-15)$ & $(12-55)$ & $(4-15)$ & $(17-54)$ & $(5-14)$ & & \\
\hline Visual closure (VC) & 8 & 9 & 8 & 9 & 8 & 9 & {$[-2 ; 1]$} & {$[-2 ; I]$} \\
\hline & $(2-16)$ & $(3-16)$ & $(2-16)$ & $(3-16)$ & $(5-13)$ & $(6-13)$ & & \\
\hline Form constancy & 29 & 9 & 29 & 9.5 & 29 & 9 & {$[-1 ; 4]$} & {$[0 ; 2]$} \\
\hline & $(8-39)$ & $(1-15)$ & $(8-39)$ & $(I-15)$ & $(8-34)$ & $(I-I I)$ & & \\
\hline $\begin{array}{l}\text { DTVP-3 } \\
\text { composite scores } \\
\text { (Comp: composite) }\end{array}$ & Comp & $\begin{array}{l}\text { Sum of } \\
\text { scaled }\end{array}$ & Comp & $\begin{array}{l}\text { Sum of } \\
\text { scaled }\end{array}$ & Comp & $\begin{array}{l}\text { Sum of } \\
\text { scaled }\end{array}$ & Comp & Scaled \\
\hline Visual motor & 103 & 21 & 103 & 21 & 100 & 20 & {$[-6 ; 9]$} & {$[-2 ; 3]$} \\
\hline integration (VMI) & $(76-139)$ & $(12-33)$ & $(79-139)$ & $(13-33)$ & $(76-121)$ & $(12-27)$ & & \\
\hline Motor-reduced & 91 & 25.5 & 89 & 24.5 & 93.5 & 26.5 & {$[-9 ; 5]$} & {$[-4 ; 3]$} \\
\hline $\begin{array}{l}\text { visual perception } \\
\text { (MRP) }\end{array}$ & $(65-159)$ & $(13-58)$ & $(65-159)$ & $(13-58)$ & $(69-116)$ & $(15-38)$ & & \\
\hline General visual & 96 & 47 & 94 & 45 & 97 & 48 & {$[-8 ; 6]$} & {$[-6 ; 5]$} \\
\hline perception (GVP) & $(73-132)$ & $(28-75)$ & $(82-132)$ & $(35-75)$ & $(73-117)$ & $(28-63)$ & & \\
\hline $\begin{array}{l}\text { Note: according to } t \\
\text { VMI }=\mathrm{EH}+\mathrm{CO} \\
\mathrm{MRP}=\mathrm{FG}+\mathrm{VC}+ \\
\mathrm{GVP}=\mathrm{EH}+\mathrm{CO}+\end{array}$ & American $n$ & of the $D$ & , scaled sc & norm is 1 & ith a standa & viation of & & \\
\hline
\end{tabular}


Table IV(b): Comparison of $95 \% \mathrm{Cl}$ for the median difference between English- and Afrikaans-speaking groups

\begin{tabular}{|l|c|c|}
\hline Sub-test & \multicolumn{2}{|c|}{$95 \%$ Cl } \\
\hline Eye-hand coordination(EH) & {$[-4 ; I I]$} & {$[-I ; I]$} \\
\hline Copying (CO) & {$[-3 ; 1]$} & {$[-2 ; 0]$} \\
\hline Figure-ground (FG) & {$[-5 ; 3]$} & {$[-I ; I]$} \\
\hline Visual closure (VC) & {$[-2 ; 0]$} & {$[-2 ; 0]$} \\
\hline Form constancy (FC) & {$[-2 ; 2]$} & {$[-I ; I]$} \\
\hline DTVP-3 composite scores & Composite & Scaled \\
\hline Visual-motor integration (VMI) & {$[-6 ; 3]$} & {$[-2 ; 1]$} \\
\hline Motor-reduced visual perception (MRP) & {$[-7 ; 2]$} & {$[-3 ; 1]$} \\
\hline General visual perception (GVP) & {$[-6 ; 2]$} & {$[-5 ; 2]$} \\
\hline
\end{tabular}

tively) were similar to the American norm for the English-speaking group, where the Afrikaans-speaking children obtained slightly higher scores, although not significant. This also corroborated with Harris who found a score of 11 .I for copying in the DTVP- ${ }^{19}$.

The results of the figure-ground (SS 8 and SS 8.5, respectively) and form constancy (SS 8.5 and 9, respectively) sub-tests of the DTVP-3 were lower than the American normative sample. The scores were also lower than those reported by Harris ${ }^{19}$ for figureground (SS 10.2) and form constancy (SS I0.2) on the DTVP-3.

Compared to the other sub-tests' results, the children's performance in the visual closure sub-test did not fall within the normative range for the English-speaking group and yielded the lowest score (SS 7.5), compared to the Afrikaans-speaking group (SS 9), and a scaled score of 9.7 reported by Harris ${ }^{19}$ on the DTVP-3 .

The English- and Afrikaans-speaking children's median composite scaled scores for visual-motor integration (SS 98.5 and 103, respectively), motor-reduced visual perception (SS 88 and 91, respectively) and general visual perception (SS 93 and 96, respectively) were below the American norm of 100 , but within the normative range of 85 to II 5 . A tendency for English-speaking children to score lower that the Afrikaans-speaking children for the composite scores was evident. In both studies, the motor-reduced visual perception (SS 88 and 9I, respectively) yielded the lowest median composite scaled scores, and a difference between the motor-reduced visual perception- and visual-motor integration median scaled scores was observed.

When comparing genders, it was noted that for the sub-tests on eye-hand coordination, boys and girls obtained the same median scaled scores in both language groups. There was a tendency, however, for boys to perform better than the girls on the figure-ground sub-test in both groups $(95 \% \mathrm{Cl}-4 ; 7$ and $95 \% \mathrm{Cl}-\mathrm{I}$ I; 3, respectively). This finding was consistent with $\mathrm{Smith}^{41}$ who did not identify any statistically significant gender differences with the DTVP- 2 .

When comparing the English- and Afrikaans-speaking children's results on each of the sub-test and composite scores, no statistically significant differences between the two groups were evident, as seen in Table IV (page 37).

\section{TVPS-3}

According to the data shown in Table V, (page 39) the English- and Afrikaans-speaking children obtained a median scaled score lower than the American normative range (SS 8 to I0), and lower than the norm of 10 for the following sub-tests: visual discrimination (both SS 7), form constancy (both SS 6), and visual closure (both SS 7). The English-speaking group furthermore obtained a median scaled score lower than the normative range (SS 8 to I0) for spatial relations (SS 6), sequential memory (SS 6), and figure-ground (SS 7), and the Afrikaans-speaking group for visual memory (SS 7). The English-speaking children obtained a median scaled score within the normative range only on the visual memory sub-test (SS 8) and the Afrikaans-speaking group on spatial relations (SS 8), sequential memory (SS 8) and figure-ground (SS 9).
The composite index scores of the English- and Afrikaansspeaking groups were similar, as indicated in the overall index scaled score (SS 85 and 85.5, respectively), basic processes (SS 84.5 and 84.5 , respectively), sequencing (SS 80 and SS 90 , respectively) and complex processes (SS 85 and 88, respectively). However, the median composite scaled scores in both studies did not compare well with the American normative range of 85 to 1 I 5 and norm of 100, as well as results from a Hong Kong study on pre-schoolers (SS 106) ${ }^{17}$. The results were also not similar to Harris's finding of an overall index scale of 100.3 , although this sample consisted of older children (6-9 years) $)^{19}$. It is therefore evident that children experienced the TVPS-3 as the most difficult of the three assessment instruments. We cannot, however, attribute the children's below normative results on the TVPS- 3 to the possibility of exhaustion when it was administered, as the test was executed first. The clinical implication of this finding is that therapists should be cognisant and perhaps not use the TVPS-3 as their first and only visual perceptual test for young children. In our study, the sample was only five years old, an age at which they were still developing these skills and not yet well developed typically seen at the age of 12 years ${ }^{42}$.

\section{Comparison of results for comparable sub-tests of the three tests}

In Table VI,(page 4I) the results of sub-tests of the three tests that were comparable are summarised per language group. The visual perceptual supplementary test of the Beery VMI- 6 is a single sub-test and was therefore not compared to the multiple sub-tests comprising the composite visual perceptual component of the other two tests. This difference between the tests prevented the comparison of the children's performance on the Beery VMI- 6 with the DTVP-3 and TVPS-3 with regard to visual perception.

A statistically significant difference was found in both the English- $(95 \% \mathrm{Cl} \mathrm{I} ; 4)$ and Afrikaans-speaking $(95 \% \mathrm{Cl} \mathrm{I}$; 4$)$ groups when the form constancy sub-tests of the DTVP-3 (SS 8.5 and 9, respectively) and the TVPS-3 (both SS 6) were compared. This finding could possibly be attributed to the fact that the DTVP-3 uses basic and familiar geometric shapes, such as circles and squares, to which five-year-old children are often exposed in pre-school and their home environment. The TVPS-3 uses more complicated shapes and unfamiliar figures and patterns that children are not exposed to. However, Harris ${ }^{19}$ found a moderate correlation (rho 0.40 ) between the scores of these two sub-tests.

The children's performance on the figure-ground sub-test of the DTVP-3 showed greater similarity (SS 8 and 8.5 , respectively) than on the TVPS-3 (SS 7and 9, respectively). On the visual closure sub-test, similar results were obtained with both the DTVP-3 (SS 7.5) and the TVPS-3 (SS 7) for the English-speaking group, consistent with a moderate correlation (rho 0.52 ) reported by Harris ${ }^{19}$. However, a statistically significant difference between these two tests was found in the Afrikaans-speaking (SS 9 and 7 respectively; $95 \% \mathrm{Cl} \mathrm{I} ; 3$ ) group, and therefore the DTVP-3 appears to be the easier test of the two. Apparently, adaptations had been made to 
Table V(a): The TVPS-3 sub-tests and composite scores, comparison of gender differences per language group

\begin{tabular}{|c|c|c|c|c|c|c|c|c|}
\hline \multicolumn{9}{|l|}{ ENGLISH } \\
\hline \multirow{3}{*}{ Sub-tests } & \multicolumn{6}{|c|}{ Median (range) } & \multirow{2}{*}{\multicolumn{2}{|c|}{$\begin{array}{l}95 \% \mathrm{Cl} \text { (median difference } \\
\text { for gender) }\end{array}$}} \\
\hline & \multicolumn{2}{|c|}{ Total group $(n=68)$} & \multicolumn{2}{|c|}{ Girls $(n=40)$} & \multicolumn{2}{|c|}{ Boys $(n=28)$} & & \\
\hline & Raw & Scaled & Raw & Scaled & Raw & Scaled & Raw & Scaled \\
\hline \multirow{2}{*}{$\begin{array}{l}\text { Visual } \\
\text { discrimination } \\
\text { (VD) }\end{array}$} & 3 & 7 & 3 & 7 & 3 & 7 & {$[-I ; I]$} & {$[-I ; I]$} \\
\hline & $(I-8)$ & $(3-12)$ & $(I-8)$ & $(3-12)$ & $(I-8)$ & $(3-12)$ & & \\
\hline \multirow{2}{*}{$\begin{array}{l}\text { Visual memory } \\
(\mathrm{VM})\end{array}$} & 5 & 8 & 5.5 & 10 & 5 & 8 & {$[-1 ; 2]$} & {$[-2 ; 3]$} \\
\hline & $(0-12)$ & $(0-25)$ & $(0-11)$ & $(0-25)$ & $(0-12)$ & $(0-18)$ & & \\
\hline \multirow{2}{*}{$\begin{array}{l}\text { Spatial relations } \\
\text { (SR) }\end{array}$} & 2 & 6 & 2 & 6.5 & 2 & 6 & {$[-I ; I]$} & {$[-1 ; 3]$} \\
\hline & $(0-12)$ & $(0-25)$ & $(0-I I)$ & $(0-25)$ & $(0-12)$ & $(0-17)$ & & \\
\hline \multirow{2}{*}{$\begin{array}{l}\text { Form constancy } \\
\text { (FC) }\end{array}$} & 3 & 6 & 3 & 6 & 3 & 6 & {$[0 ; 2]$} & {$[0 ; 3]$} \\
\hline & $(0-8)$ & $(0-25)$ & $(\mathrm{I}-8)$ & $(I-25)$ & $(0-8)$ & $(0-14)$ & & \\
\hline \multirow{2}{*}{$\begin{array}{l}\text { Sequential } \\
\text { memory (SM) }\end{array}$} & 2 & 6 & 2 & 6 & 1.5 & 5.5 & {$[0 ; 2]$} & {$[0 ; 5]$} \\
\hline & $(0-11)$ & $(0-17)$ & $(0-I I)$ & $(0-17)$ & $(0-9)$ & $(0-14)$ & & \\
\hline \multirow{2}{*}{$\begin{array}{l}\text { Figure-ground } \\
\text { (FG) }\end{array}$} & 3 & 7 & 3 & 7 & 3.5 & 8 & {$[-1 ; 0]$} & {$[-2 ; 0]$} \\
\hline & $(I-9)$ & $(3-16)$ & $(I-8)$ & $(3-14)$ & $(I-9)$ & $(3-16)$ & & \\
\hline \multirow{2}{*}{$\begin{array}{l}\text { Visual closure } \\
\text { (VC) }\end{array}$} & 2 & 7 & 2 & 7 & 2 & 7 & {$[-1 ; 0]$} & {$[-2 ; 0]$} \\
\hline & $(0-7)$ & $(0-13)$ & $(0-6)$ & $(0-I I)$ & $(0-7)$ & $(0-13)$ & & \\
\hline $\begin{array}{l}\text { Composite } \\
\text { index scores } \\
\text { (SS: scaled score) }\end{array}$ & $\begin{array}{l}\text { Sum of } \\
\text { scaled }\end{array}$ & SS & $\begin{array}{l}\text { Sum of } \\
\text { scaled }\end{array}$ & SS & $\begin{array}{l}\text { Sum of } \\
\text { scaled }\end{array}$ & SS & $\begin{array}{l}\text { Sum of } \\
\text { scaled }\end{array}$ & SS \\
\hline \multirow{2}{*}{$\begin{array}{l}\text { Overall index } \\
\text { score I }\end{array}$} & 49 & 85 & 49.5 & 85.5 & 45.5 & 84 & {$[-5 ; 8]$} & {$[-4 ; 5]$} \\
\hline & $(23-76)$ & $(67-118)$ & $(26-73)$ & $(69-118)$ & $(23-76)$ & $(67-104)$ & & \\
\hline \multirow[t]{2}{*}{ Basic processes } & 28 & 84.5 & 29.5 & 86 & 27 & 83.5 & {$[-2 ; 6]$} & {$[-1 ; 9]$} \\
\hline & $(10-47) 2$ & $(62-109)$ & $(14-45)$ & $(67-106)$ & $(10-47)$ & $(62-109)$ & & \\
\hline \multirow[t]{2}{*}{ Sequencing } & 6 & 80 & 6 & 80 & 5.5 & 75 & {$[0 ; 5]$} & {$[0 ; 25]$} \\
\hline & $(0-17)$ & $(0-135)$ & $(0-17)$ & $(0-135)$ & $(0-14)$ & $(0-120)$ & & \\
\hline \multirow{2}{*}{$\begin{array}{l}\text { Complex } \\
\text { processes }\end{array}$} & 14 & 85 & 14 & 85 & 16 & 86.5 & {$[-4 ;-1]$} & {$[-10 ; 1]$} \\
\hline & $(3-23)$ & $(58-108)$ & $(3-23)$ & $(58-108)$ & $(7-23)$ & $(61-103)$ & & \\
\hline \multicolumn{9}{|l|}{ AFRIKAANS } \\
\hline \multirow[t]{3}{*}{ Sub-tests } & \multicolumn{6}{|c|}{ Median (range) } & \multirow{2}{*}{\multicolumn{2}{|c|}{$\begin{array}{c}95 \% \mathrm{Cl} \text { (median difference } \\
\text { for gender) }\end{array}$}} \\
\hline & $\begin{array}{l}\text { Total group } \\
(n=52)\end{array}$ & & $\begin{array}{c}\text { Girls } \\
(n=32)\end{array}$ & & $\begin{array}{c}\text { Boys } \\
(n=20)\end{array}$ & & & \\
\hline & Raw & Scaled & Raw & Scaled & Raw & Scaled & Raw & Scaled \\
\hline Visual & 3 & 7 & 2.5 & 6 & 3 & 7 & {$[-1 ; 0]$} & {$[-2 ; 0]$} \\
\hline $\begin{array}{l}\text { discrimination } \\
\text { (VD) }\end{array}$ & $(0-8)$ & $(0-12)$ & $(I-8)$ & $(3-12)$ & $(0-7)$ & $(0-I I)$ & & \\
\hline Visual memory & 4 & 7 & 4 & 7 & 3.5 & 6.5 & {$[-1 ; 2]$} & {$[-2 ; 3]$} \\
\hline$(\mathrm{VM})$ & $(1-13)$ & $(2-19)$ & $(1-13)$ & $(2-19)$ & $(1-10)$ & $(2-15)$ & & \\
\hline Spatial relations & 4 & 8 & 5 & 9 & 4 & 8 & {$[-I ; 2]$} & {$[-1 ; 3]$} \\
\hline & $(0-9)$ & $(0-13)$ & $(0-9)$ & $(0-13)$ & $(0-9)$ & $(0-13)$ & & \\
\hline Form constancy & 3 & 6 & 3 & 6 & 2.5 & 5.5 & {$[-1 ; 1]$} & {$[-2 ; 2]$} \\
\hline & $(0-7)$ & $(0-12)$ & $(0-7)$ & $(0-12)$ & $(0-7)$ & $(0-12)$ & & \\
\hline Sequential & 3 & 8 & 3 & 8 & 3.5 & 8.5 & {$[-I ; I]$} & {$[-3 ; 2]$} \\
\hline memory (SM) & $(0-10)$ & $(0-16)$ & $(0-10)$ & $(0-16)$ & $(0-8)$ & $(0-13)$ & & \\
\hline Figure-ground & 4 & 9 & 4 & 9 & 4 & 9 & {$[-2 ; 1]$} & {$[-3 ; 1]$} \\
\hline$(\mathrm{FG})$ & $(I-I I)$ & $(3-19)$ & $(1-10)$ & $(3-18)$ & $(I-I I)$ & $(3-19)$ & & \\
\hline Visual closure & 2 & 7 & 2 & 7 & 1.5 & 6 & {$[0 ; 1]$} & {$[0 ; 3]$} \\
\hline & $(0-I I)$ & $(0-18)$ & $(0-5)$ & $(0-10)$ & $(0-I I)$ & $(0-18)$ & & \\
\hline
\end{tabular}




\begin{tabular}{|c|c|c|c|c|c|c|c|c|}
\hline $\begin{array}{l}\text { Composite } \\
\text { index scores } \\
\text { (SS: scaled score) }\end{array}$ & $\begin{array}{l}\text { Sum of } \\
\text { scaled }\end{array}$ & SS & $\begin{array}{l}\text { Sum of } \\
\text { scaled }\end{array}$ & SS & $\begin{array}{l}\text { Sum of } \\
\text { scaled }\end{array}$ & SS & $\begin{array}{l}\text { Sum of } \\
\text { scaled }\end{array}$ & SS \\
\hline \multirow{2}{*}{$\begin{array}{l}\text { Overall index } \\
\text { score I }\end{array}$} & 49.5 & 85.5 & 52.5 & 87 & 48.5 & 84.5 & {$[-7 ; 9]$} & {$[-5 ; 7]$} \\
\hline & $(2 I-8 I)$ & $(65-108)$ & $(2 I-8 I)$ & $(65-108)$ & $(33-8 I)$ & $(73-108)$ & & \\
\hline \multirow[t]{2}{*}{ Basic processes } & 28 & 84.5 & 28 & 85 & 27 & 84 & {$[-3 ; 6]$} & {$[-5 ; 7]$} \\
\hline & $(7-46)$ & $(39-108)$ & $(7-46)$ & $(39-108)$ & $(14-43)$ & $(67-104)$ & & \\
\hline \multirow[t]{2}{*}{ Sequencing } & 8 & 90 & 8 & 90 & 8.5 & 92.5 & {$[-3 ; 2]$} & {$[-15 ; 10]$} \\
\hline & $(0-16)$ & $(0-130)$ & $(0-16)$ & $(0-130)$ & $(0-13)$ & $(0-\mid I 5)$ & & \\
\hline \multirow{2}{*}{$\begin{array}{l}\text { Complex } \\
\text { processes }\end{array}$} & 15 & 88 & 14.5 & 86.5 & 15 & 88 & {$[-2 ; 4]$} & {$[-5 ; 10]$} \\
\hline & $(3-37)$ & $(58-143)$ & $(3-35)$ & $(58-120)$ & $(5-37)$ & $(62-143)$ & & \\
\hline \multicolumn{9}{|c|}{$\begin{array}{l}\text { Note: according to the American norm of the TVPS-3 the scaled score }- \text { norm is } 10 \text { with a standard deviation of } 3 \\
\text { Basic processes = VD + VM + SR + FC } \\
\text { Sequencing = SM } \\
\text { Complex processes = FG + VC }\end{array}$} \\
\hline
\end{tabular}

Table V(b): Comparison of $95 \% \mathrm{Cl}$ for the median difference between English- and Afrikaans-speaking groups

\begin{tabular}{|l|c|c|}
\hline \multirow{2}{*}{ Sub-test } & \multicolumn{2}{|c|}{ 95\% Cl } \\
\cline { 2 - 3 } & & Scaled \\
\hline Visual discrimination (VD) & {$[-1 ; 0]$} & {$[-1 ; 0]$} \\
\hline Visual memory (VM) & {$[-1 ; 2]$} & {$[0 ; 3]$} \\
\hline Spatial relations (SR) & {$[-2 ; 0]$} & {$[-3 ; 0]$} \\
\hline Form constancy (FC) & {$[-1 ; 1]$} & {$[-1 ; 2]$} \\
\hline Sequential memory (SM) & {$[-1 ; 0]$} & {$[-3 ; 0]$} \\
\hline Figure-ground (FG) & {$[-2 ; 0]$} & {$[-2 ; 0]$} \\
\hline Visual closure (VC) & Sum of scaled & SS \\
\hline Composite index scores (SS: scaled score) & {$[-7 ; 2]$} & {$[-4 ; 2]$} \\
\hline Overall index score I & {$[-3 ; 3]$} & {$[-5 ; 3]$} \\
\hline Basic processes & {$[-3 ; 0]$} & {$[-15 ; 0]$} \\
\hline Sequencing & {$[-3 ; 1]$} & {$[-8 ; 0]$} \\
\hline Complex processes & & \\
\hline
\end{tabular}

item linearity of the revised DTVP-3 since several studies on the DTVP-2 indicated significant differences in populations other than the normative USA sample.

No statistically significant difference was also found between the motor coordination sub-test of the Beery VMI-6 and the eye-hand coordination sub-test of the DTVP-3, although the parallel lines between which the children had to draw were spaced further apart in the Beery VMI-6 sub-test. It was similar to findings reported by Idoni ${ }^{43}$, who found a good correlation between the DTVP-2 and Beery VMI-4. On the contrary, Brown ${ }^{14}$ found that the eye-hand coordination subscale did not show a significant correlation with the VMI-6 MCST, and Harris ${ }^{19}$ also did not find a strong correlation (rho 0.04).

When the visual-motor integration sub-test of the Beery VMI-6 was compared to the copying sub-test of the DTVP-3, the children in the English-speaking group performed better in the DTVP-3 subtest, although no statistically significant difference was found This finding was similar to a previously reported significant relationship (rho $0.7 \mathrm{I})^{44}$. A statistically significant difference was found in the Afrikaans-speaking group $(95 \% \mathrm{Cl}-3 ;-1)$ when the visual-motor integration sub-test of the Beery VMI-6 (SS 9.5) was compared to the copying sub-test of the DTVP-3 (SS I I.5). This finding could be due to the DTVP-3 copying sub-test allowing the child to score between 0 and 2, with more lenient scoring criteria than the Beery VMI- 6 where the child can only score 0 or I, with each item having very specific marking criteria. The result corroborated with Harris ${ }^{19}$ who also found a week correlation between these sub-tests (rho $0.3 \mathrm{I}$ ).

\section{Comparison of the composite scores of the three tests}

The total of all of the sub-tests' scores represent the overall scores. When the median overall score of the Beery VMI-6 (for the Afrikaans- and English-speaking groups together) was compared to that of the DTVP-3, the children performed significantly better overall on the Beery VMI-6 (95\% Cl 0.7; 3.7). These findings could be due to the Beery VMI-6 having three sub-tests compared to five in the DTVP-3. Furthermore, two of the three Beery VMI-6 sub-tests require a motor output, which is required for only two of the five DTVP-3 sub-tests. Although not indicated as significantly different, Hong Kong children ${ }^{17}$ also performed overall better on the BeeryVMI-6 than on the TVPS- 3 .

The median overall score of the Beery VMI-6 showed that the children performed significantly better in this test, compared to the TVPS-3 $(95 \% \mathrm{CI} 9.7 ; 14)$. A possible explanation could be that the children found the non-motor two-dimensional based shapes and concepts used in the TVPS-3 more challenging.

When comparing the DTVP-3 to the TVPS-3, it was found that the children performed significantly better overall on the DTVP-3 (95\% Cl 8; I I). This finding could possibly be due to insufficient 
Table VI(a): Comparison of results for comparable sub-tests scaled scores of the three tests for visual perception per language group

\begin{tabular}{|c|c|c|c|c|c|c|}
\hline \multicolumn{7}{|l|}{ ENGLISH } \\
\hline Beery VMI-6 & $\begin{array}{l}\text { Median } \\
\text { (range) }\end{array}$ & DTVP-3 & $\begin{array}{l}\text { Median } \\
\text { (range) }\end{array}$ & TVPS-3 & Median (range) & $\begin{array}{c}95 \% \mathrm{Cl} \\
\text { for median } \\
\text { differences }\end{array}$ \\
\hline \multicolumn{7}{|c|}{ Non-motor components } \\
\hline & & Form constancy (FC) & $8.5(3-18)$ & Form constancy(FC) & $6(0-25)$ & {$[1 ; 4] *$} \\
\hline & & Figure-ground (FG) & $8(2-14)$ & Figure-ground (FG) & $7(3-16)$ & {$[-2 ; 0]$} \\
\hline & & Visual closure (VC) & $7.5(3-13)$ & Visual closure (VC) & $7(0-13)$ & {$[0 ; 3]$} \\
\hline \multicolumn{7}{|c|}{ Motor components } \\
\hline $\begin{array}{l}\text { Motor } \\
\text { coordination (MC) }\end{array}$ & $10(5-17)$ & $\begin{array}{c}\text { Eye-hand } \\
\text { coordination }(\mathrm{EH})\end{array}$ & $9(3-14)$ & {$[-2 ; 0]$} & & {$[0 ; 2]$} \\
\hline $\begin{array}{l}\text { Visual-motor } \\
\text { integration (VMI) }\end{array}$ & $9(4-14)$ & Copying & $10(5-19)$ & & & \\
\hline \multicolumn{7}{|l|}{ AFRIKAANS } \\
\hline Beery VMI-6 & Median (range) & DTVP-3 & Median (range) & TVPS-3 & Median (range) & $\begin{array}{l}95 \% \mathrm{Cl} \text { for median } \\
\text { differences }\end{array}$ \\
\hline \multicolumn{7}{|c|}{ Non-motor components } \\
\hline & & Form constancy (FC) & $9(1-15)$ & Form constancy(FC) & $6(0-12)$ & {$[1 ; 4] *$} \\
\hline & & Figure-ground (FG) & $8.5(4-15)$ & Figure-ground (FG) & $9(3-19)$ & {$[-2 ; 2]$} \\
\hline & & Visual closure (VC) & $9(3-16)$ & Visual closure (VC) & $7(0-18)$ & {$[1 ; 3]^{*}$} \\
\hline \multicolumn{7}{|c|}{ Motor components } \\
\hline $\begin{array}{l}\text { Motor } \\
\text { coordination (MC) }\end{array}$ & $10(4-17)$ & $\begin{array}{c}\text { Eye-hand } \\
\text { coordination (EH) }\end{array}$ & $9(2-14)$ & {$[-3 ;-1]^{*}$} & & {$[0 ; 2]$} \\
\hline $\begin{array}{l}\text { Visual-motor } \\
\text { integration (VMI) }\end{array}$ & $9.5(6-16)$ & Copying & $11.5(5-19)$ & & & \\
\hline
\end{tabular}

Table VI(b): Comparison of $95 \% \mathrm{Cl}$ for the median difference between English- and Afrikaans-speaking groups.

\begin{tabular}{|l|c|}
\hline & $95 \% \mathbf{C l}$ for the median difference \\
\hline Form constancy & {$[-2 ; \mathrm{I}]$} \\
\hline Figure-ground & {$[-2 ; \mathrm{I}]$} \\
\hline Visual closure & {$[-2 ; \mathrm{I}]$} \\
\hline Motor coordination versus eye-hand coordination & {$[-1 ; \mathrm{I}]$} \\
\hline Visual-motor integration versus copying & {$[0 ; 2]$} \\
\hline
\end{tabular}

exposure to complex two-dimensional visual perceptual activities in the current curriculum and/or limitations in the teachers' repertoire. It could also be attributed to the TVPS-3 having more sub-tests, or the absence of motor components in the TVPS-3 may have a substantial influence on the child's performance. In contrast, a South African ${ }^{25}$ study on a sample of 174 Grade I to Grade 4 learners with previous editions of the tests (DTVP-2 and TVPS-R), found a strong correlation (rho 0.654 ) between the two tests.

\section{LIMITATIONS, IMPLICATIONS FOR PRACTICE AND RECOMMENDATIONS}

The limitations associated with this study were, firstly, the small sample of children recruited from one geographical area (Bloemfontein). Secondly, although different quintile schools (quintile 3, 4 and 5) were included, the socio-economic background, differences in the school settings and educational background of the children, were not formally taken into account. Finally, no differences other than language, gender and curriculum have been taken into account in this small sample.

Despite these limitations, the implication for practice is that the results can only be generalised to similar South African popu- lations. Recommendations with regard to clinical practice include the following:

* Since the discrepancy in culture, language and curriculum may indicate that each population being assessed using these tests, OTs should apply, interpret and convey the results of these tests with caution.

- These tests' prescribed instructions should be translated into the South African official languages in order to avoid conceptual misunderstanding, which might affect test results.

* The TVPS-3 should not be used as the only visual perceptual test in the assessment process to guide intervention planning, but should be used in combination with the Beery VMI-6 and/or DTVP-3.

Based on the interpretation of the results of this study, the authors recommend further research on the Beery VMI-6, DTVP3 and TVPS-3 on larger samples representing different cultural, socio-economic and language groups from different educational settings in South Africa; the development of contextual-specific instruments; and standardisation of existing international instruments in the South African context to have local normative value for the children being assessed using these tests. 


\section{CONCLUSION}

The aim of this study was to describe the visual perception and visual-motor performance of five-year-old children in Bloemfontein, South Africa, by using the Beery VMI-6, DTVP-3 and TVPS-3 measurement instruments. The findings provide occupational therapists using these tests with evidence of how the norms of the South African sample compare with the American normative sample. Children's performance on the Beery VMI- 6 and the DTVP-3 compared well to the American normative sample, but for the TVPS-3, the children scored below average for the majority of sub-tests, and it was considered as the most difficult of the three tests. This research indicates that no significant differences between language groups were identified. When the composite scores of the Beery VMI-6 and DTVP-3 were compared, children performed significantly better than on the TVPS-3.

The Beery VMI-6, DTVP-3 TVPS-3 are reliable and valid instruments to be used by clinicians, educators and researchers, although more research is needed to assess its psychometric properties and validate its use in a cross-cultural context such as the diverse South African population.

\section{ACKNOWLEDGMENTS}

The participants, their parents, and school staff; Dr. Daleen Struwig, medical writer/editor, Faculty of Health Sciences, University of the Free State, for technical and editorial preparation of the manuscript; the volunteer student researchers Lee Hattingh, Megan Nell, Clarette Cronje, Susan Venter, Monique De Beer, Shameelah Faywers, Kelly Thomson, Carmen Smith, Corli Wepener, Robyn Leigh, Ronel Weyers, Marzel van Wyk,

\section{REFERENCES}

I. American Occupational Therapy Association. Framework: Domain and Process, $3^{\text {rd }}$ ed. American Journal of Occupational Therapy. 20I4; 68(SuppII): SI-S48.

2. World Health Organization. How to use the ICF: a practical manual for using the International Classification of Functioning, Disability and Health (ICF). Exposure draft for comment. Geneva: WHO, 2013.

3. Rudman $D$ and Hannah $S$. An instrument evaluation framework: description and application to assessments of hand function. Journal of Hand Therapy. 1998; II: 266-277.

4. Beery KE and Beery NA. Administration, scoring and teaching manual for the Beery-VMI. $6^{\text {th }}$ ed. San Antonio, TX: Pearson, 2010.

5. Hammil D, Pearson N and Vores J. Developmental test of visual perception examiner's manual. $3^{\text {rd }}$ ed. Austin, TX: Pro-Ed, 2014.

6. Martin NA. Test of visual perceptual skills (TVPS-3). $3^{\text {rd }}$ ed. Novato, CA: Academic Therapy Publications, 2006.

7. Visser MM, Nel M, Jansen T, Kinmont L, Terblanché $S$ and Van Wyk J. Visual perception of five-year-old, English-speaking children in Bloemfontein using the Beery $6^{\text {th }}$, DTVP-3, and TVPS-3. South African Journal of Occupational Therapy. 2017; 47: 17-26.

8. Clarke K. Construct validity of the Developmental Test of VisualPerception Third Edition (DTVP-3) in Western Australian primary school children. 20I5. http://ro.ecu.edu.au/theses_hons/I474. (accessed I2 April 2018).

9. Brown T, Bourne R, Sutton E, Wigg S, Burgess D, Glass S, Elliott S and Lalor $A$. The reliability of three visual perception tests used to assess adults. Perceptual Motor Skills. 2010; II I: 45-59.

10. Brown T. Construct validity of the three motor-reduced subscales of the Developmental Test of Visual Perception - Adolescent and Adult (DTVP-A): a Rasch analysis model evaluation. British Journal of Occupational Therapy. 20I I; 74: 66-77.

II. Brown T, Elliot S, Bourne R, Sutton E, Wigg S, Morgan D, Glass S and Lalor A. The discriminative validity of three visual perceptual tests. New Zealand Journal of Occupational Therapy. 201 I; 58:14-22.

12. Brown T and Murdolo Y. The Developmental Test of Visual Perception-Third Edition (DTVP-3): a review, critique, and practice implications. Journal of Occupational Therapy, Schools and Early Intervention. 2015; 8: 336-354.

13. Brown T and Link J. The association between measures of visual perception, visual-motor integration, and in-hand manipulation skills of school-age children and their manuscript handwriting speed. British Journal of Occupational Therapy. 2015; 79: 163-171.

14. Brown T. Validity and reliability of the Developmental Test of Visual Perception - Third Edition. Occupational Therapy in Health Care. 2016; 30: 272-288.

I5. Fang Y, Wang J, Zhang Y and Qin J. The relationship of motor coordination, visual perception, and executive function to the development of 4-6-year-old Chinese preschoolers' visual-motor integration skills. BioMed Research International. 2017; 2017: 6264254

16. Chiu E, Wu W, Chou C, Yu M and Hung J. Test-retest reliability and minimal detectable change of the Test of Visual Perceptual Skills Third Edition in patients with stroke. Archives of Physical Medicine and Rehabilitation. 2016; 97: 1917-1923.

17. Ho WC, Tang MM, Fu CW, Leung KY, Pang PC and Cheong AM. Relationship between vision and visual perception in Hong Kong preschoolers. Optometry and Vision Science. 20I5; 92: 623-63I.

18. Chiu EC, Yu MY, Wu WC, Chou CX, Hung JW and Chen PC. Validation of the Test of Visual Perceptual Skills - Third Edition in patients with stroke. Disability and Rehabilitation. 2017; Sep 19: I-6.

19. Harris M. The validity of standardised visual perceptual tests in identifying specific learning disabilities in children from Gauteng Province, South Africa. Presentation at the $35^{\text {th }}$ Occupational Therapy Association (OTASA) Congress, WITS University, 14-16 July 2016.

20. Van der Merwe J, Smit N and Vlok B. A survey to investigate how South African occupational therapists in private practice are assessing and treating poor handwriting in foundation phase learners: Part I demographics and assessment practices. South African Journal of Occupational Therapy. 20I I; 4I: 3-II.

21. Janse van Rensburg E, Nel R, Johnson C, Rawlins C, Smith CT, Janse van Rensburg E, van Greunen I, de Beer M, and Voster S. Describing the use of assessments by occupational therapists in paediatric practice in South Africa. Unpublished undergraduate study. Bloemfontein; University of the Free State, 2017.

22. Lim CY, Tan PC, Koh C, Koh E, Guo H, Yusoff ND, See CQ and Tan T. Beery-Buktenica Developmental Test of Visual-Motor Integration (Beery-VMI): lessons from exploration of cultural variations in visual-motor integration performance of pre-schoolers. Child: Care, Health and Development. 20I5; 41: 213-221.

23. Cheung PP, Poon MY, Leung M and Wong R. The Developmental Test of Visual Perception-2 normative study on the visual-perceptual function for children in Hong Kong. Physical and Occupational Therapy in Paediatrics. 2005; 25: 29-43.

24. Visser M, Cronjé M, Kemp B, Scholtz M, van Rooyen W and Nel M. The DTVP-2 visual closure sub-test: a closer look. South African Journal of Occupational Therapy. 20I 2; 42: 2I-25.

25. Richmond $\mathrm{J}$ and Holland $\mathrm{K}$. The relationship between a teacher check list and standardised tests for visual perception skills: a South African remedial primary school perspective. South African Journal of Occupational Therapy. 2010; 40: 9-16.

26. Brown T and Hockey SC. The validity and reliability of developmental test of visual perception, $2^{\text {nd }}$ edition (DTVP-2). Physical and Occupational Therapy in Paediatrics. 2013; 33: 426-439.

27. McDonald CA, Volker MA, Lopata C, Toomey JA, Thomeer ML, Lee GK, Lipinski AM, Dua EH, Schiavo AM, Bain F and Nelson AT. VMI-VI and BG-II KOPPITZ-2 for youth with HFASDs and typical youth. Journal of Psychoeducational Assessment, 2014; 32: 379-389.

28. Martin NA. Test of visual perceptual skills (TVPS-4) 4th ed. Novato, CA: Academic Therapy Publications, 2017.

29. Free State Department of Basic Education (FS DoE). Education Management Information System (EMIS) section. EMIS Portal. www.fsdoe.fs.gov.za/emisportal(accessed I 2 April 20I8).Harvey EM, Leonard-Green TK, Mohan KM, Kulp MT, Davis AL, Miller JM, Twelker JD, Campus I and Dennis LK. Interrater and test-retest reliability of the Beery Visual-Motor Integration in schoolchildren. Optometry and Vision Science, 2017; 94: 598-605.

30. Brown T, Mullins $E$ and Stagnitti K. The concurrent validity of three visual perception tests used with adults. Occupational Therapy in Health Care, 2009; 23: 99-118.

3I. Rens Z. The standardization of the Beery-Buktenica developmental test of visual-motor integration with supplemental developmental tests of visual perception and motor coordination ( $4^{\text {th }}$ edition, revised 1997) on an Eastern Cape population aged 7 years 0 months to 7 years 3 months. Johannesburg: University of the Witwatersrand, 2009. 
32. Buktenica NA. Identification of potential learning disorders. Journal of Learning Disabilities. I97I; 4: 35-39.

33. Green RR, Bigler ED, Froehlich A, Prigge MB, Travers BG, Cariello AN, Anderson JS, Zielinski BA, Alexander A, Lange $\mathrm{N}$ and Lainhart JE. Beery VMI performance in autism spectrum disorder. Child Neuropsychology. 2016; 22: 795-817.

34. Van Rombergh JA. Die voorkoms van visuele-persepsieprobleme en die effektiwiteit van Arbeidsterapie groepbehandeling onder Gr. I kleurling kleuters [The prevalence of visual-perceptual problems and the effectivity of occupational therapy group treatment among Gr. I coloured children]. Master's dissertation. Bloemfontein: University of the Free State, 2006.

35. Coallier M, Rouleau N, Bara F and Morin MF. Visual-motor skills performance on the Beery VMI: a study of Canadian kindergarten children. The Open Journal of Occupational Therapy. 20I4; 2: article 4. https://scholarworks.wmich.edu/ojot/vol2/iss2/4/ (accessed 12 April 2018).

36. Parsa M. Adolescence psychology. $3^{\text {rd }}$ ed. Tehran: Besat Press, 1988.

37. Lai MY and Leung FKS. Visual perceptual abilities of Chinesespeaking and English-speaking children. Perceptual and Motor Skills. 20I2; I 14: 433-445.

38. McCrimmon AW, Altomoare AA and Matchullis TL. Test review: the Beery Developmental Test of Visual-Motor Integration $6^{\text {th }}$ edition. Journal of Psychoeducational Assessment. 2012: 30: 588-592.

39. Beery KE and Beery NA. Test review: the Beery Developmental Test of Visual-Motor Integration (6th ed.). Journal of Psychoeducational Assessment. 2010; 30: 588-592.

40. Smith M. The suitability of the DTVP-2 as a measurement instrument for 5 year and 6 months to 5 years and II months English-speaking children in urban South Africa. Master's dissertation. Bloemfontein: University of the Free State, 20I5. http://scholar.ufs.ac.za:8080/ xmlui/handle/ I 1660/234I (accessed I2 April 20I8).

4I. Braddick O, Atkinson J. Development of human visual function. Vision Research. 201 I; 51: I588-1609.

42. Idoni J, Taub MB and Harris PA. A comparison of two tests of visual-motor integration. Optometry and Visual Performance. 2014; 2: 170-174.

43. Swart $\mathrm{S}$. The relationship among three perceptual-motor skills in children aged six years referred for occupational therapy in Tshwane East. Master's dissertation. Pretoria: University of Pretoria, 2016. https://repository.up.ac.za/handle/2263/5 I 282 (accessed I2 April 2018).

\section{Corresponding author}

M Visser

Email: vissermm@ufs.ac.za 